\title{
Andrés Piquer and the Neo-Hippocratic Teaching of Medicine in Eighteenth Century Spain
}

\author{
Jesús Angel y Espinós ${ }^{1}$
}

\begin{abstract}
Summary
Eighteenth century Spain witnessed a revaluation of the Hippocratic works as a result of the growing criticism of the Galenism dominant in the Spanish University of the time. Probably the most important author in this reformist trend was Andrés Piquer y Arrufat (1711-1772), eclectic philosopher, university professor and doctor to the Kings Fernando VI and Carlos III.

His desire to transform medical university instruction following Hippocrates' rules led him to make some of the first Hippocratic treatises from ancient Greek to Spanish, for the first time. Among these treatises, the translation and commentary of Epidemics 1 and 3, and partially of Epidemics 2 , are especially noteworthy. This medical and philological work relates not only to Hippocrates but also to the medical concepts of Thomas Sydenham, the English Hippocrates. The Clinical Histories and descriptions of katastasies in his Observationes medicae (London, 1676) exerted a great influence not only on A. Piquer but also on many Spanish doctors. Moreover, the works of Herman Boerhaave and especially of his pupil Gerhard van Swieten left their imprint on the ideas of the Spanish doctor.

Besides his translations, A. Piquer wrote many treatises based on Hippocratic teaching for university students, in Latin as well as in Spanish. His Praxis Medica was translated into Portuguese and his Tratado de las calenturas (About the fevers) into French.
\end{abstract}

Nowadays, historians generally agree that the seventeenth century was a period of political and economic decline for the Spanish Empire, especially in its second half. As the sickly and handicapped Charles II,

\footnotetext{
${ }^{1}$ This paper is part of Research Project DGICYT (HUM-2006-13200), under the title 'Estudios sobre el Corpus Hippocraticum y su influencia' and with the direction of Ignacio Rodríguez Alfageme. This project has the financial support of the Spanish Ministry of Science and Technology.
} 
the last king of the House of Habsburg, neared death without producing an heir, the European monarchies started intriguing to control the Spanish realms, plotting in the Spanish Court to obtain the inheritance of the throne. In accord with what Charles II stated in his will when he died in November 1700, the Duke of Anjou, grandson of French King Louis XIV, was elected as his successor and became Philip V, the first Bourbon to occupy the Spanish throne. Austria, Holland and England refused to recognize Philip V and signed a Treaty of Alliance in 1701. The War of Spanish Succession broke out when the allied armies invaded Spain in order to drive out the Bourbon king and to establish the Archduke Charles, the Austrian pretender to the throne. The Treaty of Utrecht (1713) marked the end of the hostilities. Under the treaty, Philip would be crowned king. Spain paid the price of its defeat in dominions; Spain lost all its European possessions and gave Britain Gibraltar and special privileges in trade with America.

The reign of Philip V (1700-1746) ${ }^{2}$ ushered in the Spain of the Enlightenment a period of harmonious foreign relations, reforms and interior development. Due to the collaboration of France, Spain won back Naples and Sicily His son, Ferdinand VI (1746-1759), was concerned with the domestic recovery of the country rather than the extension of its power in Europe. He defended a policy of neutrality and he urged the construction of a powerful fleet to protect Spanish interests in America. As Ferdinand VV died without an heir, his successor was his half-brother Charles III (1759-1788), who had already been king of Naples. Charles III turned his attention to internal problems, launching a programme of far-reaching economic, cultural and religious reforms. He introduced the very latest in urban reform ideas from his native Naples. This was the time when Madrid was transformed into a modern city. Although there were riots in Madrid and other provinces against the programme's implementation, the nation's intellectuals were receptive to the ideas of the Enlightenment and the Encyclopaedia of Diderot and d'Alembert. Charles III died in 1788, a year before the outbreak of the French Revolution. His son, Charles IV (1788-1808), was a weak man, who was not able to carry through the reforms begun by his father.

There is no doubt that the first Bourbons aimed at improving social conditions in Spain, after the moral and political stagnation of the last kings of the House of Habsburg, a period of crisis which nevertheless

\footnotetext{
${ }^{2}$ In 1724 Philip V abdicated in favour of his son Louis I, who died a few months later in the same year. Because of this misfortune, Philip V occupied the throne again.
} 
was witness to a cultural Renaissance. In eighteenth century Spain, cultural and scientific associations were created all over the country such as, for example, the Royal Colleges of Surgery in Cadiz (1748), Barcelona (1760) and Madrid (1780). ${ }^{3}$ Foreign scientists were brought to the country and, at the expense of the Crown or with grants of official institutions, many Spaniards were sent to study abroad. This was the period when Spanish students of medicine came into contact with the teachings of Friedrich Hoffmann (1660-1742), Herman Boerhaave (1668-1738) and Gerhard van Swieten (1700-1772), disciple of the latter, for the first time and when university professors decided to turn back to Hippocrates and away from a reactionary Galenism, which was already distorted by Scholastic philosophy and the Catholic religion. The University of Valencia was the main centre of the movement against Galen and Aristotle. Andrés Piquer studied medicine and taught at this University until 1751, when the Royal Court of Ferdinand VI appointed him as one of the king's private doctors. After Charles III succeeded Ferdinand VI, Andrés Piquer continued to hold this office until 1772, the year of his death. ${ }^{4}$

Unfortunately, in the end, this social and scientific development collapsed. Crucial among the factor responsible for the sudden decline were the French Revolution, whose horrors produced a conservative reaction in the Spanish nobility, crown and society, and the French invasion and the subsequent War of Independence against Napoleon's army (1808-1814), which had the effect of squandering all the years and money invested. Moreover, an important factor in the failure of the Spanish Enlightenment was the impatience of the governments, which considered progresses too slow, and also their naîve trust in scientific education as a remedy for all problems. ${ }^{5}$

To summarize, it was in this period of lights and shadows, of forward-looking reforms and deep-rooted traditions, when Andrés Piquer y Arrufat (Fórnoles, province of Teruel, 1711 - Madrid, 1772) lived and wrote his medical and philosophical works. Andrés Piquer belongs to the long tradition of Spanish humanistic doctors like, for example, the Andalusian Ibn al-Rushd (Averroes, $\dagger$ 1198), physician who gained his primary reputation as commentator of Aristotle, Gómez

\footnotetext{
${ }^{3}$ On the Royal Colleges of Surgery and their role in the society of the time see Granjel (1979) 69-72.

${ }^{4}$ With regard to the biography and the works of Andrés Piquer see Mindán Manero (1991), probably the best book about the Spanish doctor and philosopher. See also Sanvisens Marfull (1953), Guy (1983) 152-161 and Abellán (1988) 449-461.

${ }^{5}$ See Holub (1976) and Perdiguero (1992) 160-162.
} 
Pereira (ca. 1500-ca. 1558), who was doctor of Prince Charles, the insane son of Philip II, and is considered to be the forerunner of Descartes due to his theories about the animal automatism, Miguel Servet (ca. 1511-1553), who discovered the pulmonary circulation of blood $^{6}$ and was burnt at the stake in Calvin's Geneva because of his heretical theories, and, finally, Santiago Ramón y Cajal (1852-1934), recipient of the Nobel Prize for medicine in 1906 thanks to his research in neurology and the writer of critical essays, etc.

Regards Andrés Piquer, it is known that in 1734, the same year as his graduation from the University of Valencia in medicine, ${ }^{7}$ he obtained a post of second rank as a teacher at this University and, the next year, published his first work, Medicina vetus et nova. In 1739 an epidemic outburst broke out in a little village near Valencia and Piquer was ordered to inform the authorities and to write a report about the events. It was probably during the composition of this text that Piquer began to devote his attention to epidemic diseases. It is true to say that the success of this account was the real starting-point of the professional career of Piquer, since he went on to become a prestigious doctor and was appointed professor of anatomy in 1742 . He held this chair until 1751, when he accepted the king's invitation to be court doctor. Throughout this period, Piquer devoted himself to the study of mathematics, physics, history and Ancient Greek, and came to espouse iatromechanical arguments, as can be seen in his treatise About the fevers (Tratado de las calenturas). This work, published in 1751, was the last written while he was professor in Valencia. ${ }^{8}$

In this regard we should point out that Piquer radically changed his way of thinking after his arrival to Madrid, renouncing his former mechanistic ideas and embracing scepticism. It is difficult to identify the reasons for this evolution, but one might be tempted to suggest that he probably began to doubt his own convictions when his wife died in 1750 and he realized that not only the mechanistic but also all the

\footnotetext{
${ }^{6}$ In fact, the discoverer of the blood circulatory system was the Egyptian Ibn al-Nafis (ca. 1213-1288). However, this great medical finding, which was re-discovered by modern science after a lapse of three centuries, remained unknown until 1924, when an Egyptian student of medicine found the theories of his compatriot in ancient Arabic manuscripts.

${ }^{7}$ Piquer had previously studied philosophy at the same University (1727-1730).

${ }^{8}$ This treatise enjoyed an international success thanks to its translation into French, Traité des fièvres traduit de l'espagnol en français... (Amsterdam/Montpellier, 1776). A disciple of Andrés Piquer, Narciso Peiri, made a Latin résumé under the title De febribus ad Tyrones (Valencia, 1784). See Mindán Manero (1991) 71.
} 
remaining systems were ineffective for understanding human disease and human body. Another factor to consider is the influence of his mentor, Gregorio Mayáns y Siscar, whose philosophy was contrary to any system. ${ }^{9}$ As a consequence, Piquer's first work written in Madrid, De medicinae experimentalis praestantia (1752), was a brief tract against the mechanistic system in defence of anti-mechanistic scepticism. These arguments were repeated in the Speech about the mechanistic system (Discurso sobre el sistema del mecanismo, Madrid 1768).

Apart from these theoretical works about the way of understanding medical science, another feature to take into account is Piquer's great interest in the didactics of medicine. His translation and commentary of some of Hippocratic treatises is probably one of the most important pedagogic works of eighteenth century Spain. As has been noted, after graduating in medicine, Piquer began to study Ancient Greek, for he considered that a doctôr had to master not only Latin but also Ancient Greek in order to return to the bases of the Greek medicine, as the unique way of progressing in medicine. Piquer made the first translations from Ancient Greek into Spanish ${ }^{10}$ of the Hippocratic Prognostic (1757), ${ }^{11}$ Epidemics 1 (1761), ${ }^{12}$ and Epidemics 3 and

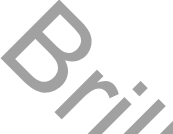

9 A very interesting essay about Gregorio Mayáns y Siscar, his life, works and friendship with Piquer may be found in Peset i Llorca (1975). Gregorio Mayáns y Siscar (1699-1781) was an erudite who was in correspondence with Voltaire, Muratori, etc. He exerted great influence on the thinking of the scientific and literary community of Enlightened Spain.

${ }^{10}$ In 1699 Alonso Manuel Sedeño de Mesa published a translation with commentaries of Hippocrates' Aphorisms, whose title announced that it was made from ancient Greek, but it was really question of a paraphrase of the Latin version. See Granjel (1972) 170, López Férez (1983) 237 and especially Martínez Pérez \& Santamaría Hernández (2002) 43-78. In the latter book the authors try to find reliable facts about the biography of Sedeño de Mesa, whose life, including the dates of birth and death, remains shrouded in mystery.

11 Las obras de Hippócrates más selectas con el texto griego y latino puesto en castellano e ilustrado con las observaciones prácticas de los antiguos y modernos para la juventud española que se dedica a la medicina, por el Dr. Andrés Piquer, tomo I, ed. Joaquín Ibarra, Madrid 1757. (The greatest works of Hippocrates with the Greek and Latin texts translated into Spanish \& illustrated with the practical observations from Ancients and moderns for the Spanish youth dedicated to medicine, by the Dr. Andrés Piquer, first volume).

12 Las obras de Hippócrates más selectas, ilustradas por el Dr. Andrés Piquer, tomo II, ed. Joaquín Ibarra, Madrid 1761. (The greatest works of Hippocrates, illustrated by Dr. Andrés Piquer, second volume). 
selected passages of Epidemics 2 (1770) and commented the texts. ${ }^{13}$ Piquer thought that Prognostic, Epidemics 1 and 3 were authentic, and that Epidemics 2 was not. As a result, he decided to comment just the fragments he considered of interest to students. Piquer's commentary of Prognostic achieved such success that it was translated into French in $1822 .^{14}$

In the first volume, Piquer wrote an erudite and full prologue (Prefación) whose goal was to acquaint young doctors not only with the texts of Hippocrates, which the students could read in Latin, but also with different features of the Hippocratic legacy. This didactic aim must be related to the Enlightenment programme of the first Bourbon kings. Moreover, at that time there were many social and scientific movements intended to regenerate the overall cultural level of each Spanish region Nevertheless, the problems of University education were not solved. With this instructive purpose in mind, in the prologue Piquer discusses the question of determining the genuine works of the Greek doctor, ${ }^{15}$ compares the writings of Hippocrates and Galen, etc. The text format of the Hippocratic treatises is in two columns. In the first column are the Greek texts, followed by the Latin translation, ${ }^{16}$ and in the second one is Piquer's translation. The lower part of each page is devoted to profuse commentaries in which the doctor displays his great scholarship and shows that he is familiar both with the rich tradition of sixteenth century Spain ${ }^{17}$ and with contemporary European doctors. As the reader comes to realize, Piquer fulfilled his plan for illustrating the Hippocratic treatises with the practical observations of ancient and modern doctors. Consequently, in Piquer's commentaries the influence of Thomas Sydenham (1624-1689), the famous Enghish doctor, and

\footnotetext{
${ }^{13}$ Las obras de Hippócrates más selectas, ilustradas por el Dr. Andrés Piquer, tomo III, ed. Joaquín Ibarra, Madrid 1770. (The greatest works of Hippocrates, illustrated by Dr. Andrés Piquer, third volume). On these three works and the subsequent editions and reprints see Mindán Manero (1991) 75-80.

${ }^{14}$ Les Pronostics d'Hippocrate, commentés par A. Piquer, d'après les observations pratiques des auteurs tant anciens que modernes, ouvrage traduit de l'espagnol et augmenté d'une notice biografique, par J.B.P. Laborie, Montpellier, 1822.

${ }^{15}$ For a discussion of Piquer's attitude towards the Hippocratic question see Ángel y Espinós (2002).

${ }^{16}$ Piquer used for Prognostic the Latin translation of Cristóbal de Vega (Lyon 1551) and for Epidemics that of John Freind (London 1717). The Greek text of Prognostic belongs to the edition of Anuce Foës (Frankfurt 1595) and that of Epidemics to John Freind (London 1717).

17 For the editions, translations and commentaries about Hippocrates written by Spaniards in the sixteenth century see Santander Rodríguez (1971).
} 
Gerhard van Swieten (1700-1772), the founder of the Alte Wiener Schule, is notable. ${ }^{18}$

Moreover, just as Hippocrates had done earlier, Piquer considered that medicine had to be experimental and based on naked eye observations without the use of barometer or thermometer. Consequently, Piquer judged Hippocrates to be 'the main author of the experimental medicine. ${ }^{19}$ Nevertheless, we cannot mistake Piquer's experimental medicine for our concept of laboratory experimentation. Piquer's image of Hippocrates has to be understood in the context of the habitual procedure of creating a particular Hippocrates, serving the purposes of each period or of each interpreter. ${ }^{20}$ According to this tendency, Galen's reputation suffered badly by comparison with Hippocrates' status, for the Spanish Galenism, after the period of the great sixteenth century doctors like Cristóbal de Vega (1510-1573) or Francisco Valles (1524-1592), ${ }^{21}$ had been degenerated into obscure and scholastic interpretations. Unfortunately, this dogmatic Galenism, which often had norelation with the great doctor of Pergamum, was the dominant doctrine in the Spanish University when Piquer studied medicine, although important doctors of the time, like the iatrochemical Diego Mateo Zapata (1664-1745) or the sceptic Martín Martínez (16841734), disagreed with this way of teaching and understanding medicine. Without any doubt, the Anti-Galenic doctors left their imprint on Piquer, since he even blamed, unjustifiably, Galen for falsifying the Hippocratic theories to his own advantage.

In our opinion, the doctrinal background of Piquer's transformation of Hippocrates can be found especially in the medical thought of Thomas Sydenham, whose huge work Observationes medicae circa morborum acutorum historiam et curationem (London, 1676$)^{23}$ and

\footnotetext{
${ }^{18}$ On the influence of van Swieten and the Alte Wiener Schule on Spanish Enlightened medicine see López Piñero (1973).

${ }^{19}$ See Prologue (Prefación) to the first volume, LIX.

${ }^{20}$ On the transformation of Hippocrates in Piquer's thought see Ángel y Espinós (in press).

${ }^{21}$ A remarkable study of the medical Humanism of the sixteenth century at the University of Alcalá de Henares, where both doctors were teachers, may be found in Martín Ferreira (1995).

${ }^{22}$ See Prologue (Prefación) to the first volume, XXXVII-XLI.

23 This work is the enlargement of the Methodus curandi febres, propriis observationibus superstructa (London 1666, $1668^{2}$ with an additional chapter on the plague). As Cunningham (2001) 103 points out: 'The title of this work, in both its versions, is significant, for it calls on observation, and in particular one's own
} 
especially the case-histories it contains, had much to do with Piquer's interest in clinical medicine. Sydenham's fundamental idea of species morbosa is responsible for some observations of the Spanish doctor. Like the English doctor, Piquer postulated that, in order to draw a complete and graphical picture of a disease, observation had to be based on morbid phenomena we can describe; in other words: the doctor had to give up seeking the remote causes of the disease and philosophizing about its hypothetical constitution. According to Sydenham's tendency towards the characterization and classification of diseases, Piquer asserted the primacy of general observations over individual ones, because the first ones show us the constant and recurrent behaviour of Nature and its creatures. ${ }^{24}$

As has previously been seen, Piquer began to take an interest in epidemic diseases after his report about the epidemic outbreak of 1739 . His main work in this field was the translation, with rich commentaries, of Hippocrates' Epidemics 1 and 3, and of some chapters of Epidemics 2. The authority of Sydenham's conception of medicine is evident in these translations, since the quotations of the English doctor are found throughout. These translations and commentaries had a double goal: on the one hand, the encouragement of the university students of medicine as a means to regenerate the education in the University, and, on the other, the socially advanced aim of improving the medical craft and extending medical benefits to the whole society, including the poor, especially with regard to diseases they suffered from most - epidemics. This second goal can be directly related to Sydenham's works, since it has been argued that his medical thought had to be explained on the basis of his religious beliefs according to which the doctor had to commit himself to extending the welfare to all the social classes. ${ }^{25}$ Moreover, Piquer was an excellent writer of case-histories. In his narrations of the fatal pathological processes of Queen María Bárbara and of King Ferdinand VI, the stamp of Sydenham can be appreciated. In the full case-history about the king, Piquer took account of all the details and even remarked that the king did not heed doctor's advices. Remarkable in Piquer's descriptions is the importance of the Hippocratic concept of katastasis, revived in the seventeenth century by the Sydenhamian constitutio epidemica. Sydenham, and later Piquer,

observation, as the basis of medical improvement.' On the Sydenhamian case-histories see Laín Entralgo (1950) 137-177.

${ }^{24}$ See Prologue (Prefación) to the first volume, LVI.

${ }^{25}$ On this argumentation see Cunningham (2001) 102-104 and Martensen (2001) 121132. 
considered Hippocrates to have been empirical and averse to theory and the founder of a new scientific method based on the accurate and tireless scrutiny of the effects of the environment on both disease and the patient.

In relation to the high standing of Sydenham in Spanish medicine, it is worth noting that one of the doctors who, together with Piquer, took care for the ill King Ferdinand VI was Gaspar Casal (1680-1759), whose posthumous work Natural and Medical History of the Principality of Asturias (Historia Natural y Médica del Principado de Asturias, Madrid, 1762) is the best example of meteorological medicine in eighteenth century Spain. Thanks to Sydenham's descriptive method and to the fundamental notion of species morbosa, Gaspar Casal was able to describe pellagra, a disease due to the ingestion of spoiled maize, which causes cracking of the skin and often leads to insanity. ${ }^{26}$

With respect to Piquer, there is no doubt that the ascendancy of Sydenham was crucial to the research for Epidemics 1 and 3, and some chapters of Epidemies 2.Nevertheless we should point out that this work, including the translation into vernacular with commentaries of Prognostic, has also to be placed in the erudite Spanish Renaissance tradition. ${ }^{27}$ In the sixteenth centuíry Cristóbal de Vega wrote Latin versions and commentaries on Prognostic and Aphorisms. ${ }^{28}$ These works are noticeable in his philological remarks, ${ }^{29}$ which witness the doctor's profound knowledge of ancient languages. Piquer will use this Latin translation of Prognostic in his commentary about this Hippocratic treatise (1757). A contemporary as well as a rival of Cristóbal de Vega was Francisco Valles, known as 'the divine', who wrote translations with commentaries on several Fippocratic treatises among which the works dedicated to Prognostic ${ }^{30}$ and to Epidemics are of special interest. His In libros Hippocratis de morbis popularibus commentaria magnam utriusque medicinae, theoricae inquam \& practicae, partem continentia (Madrid, 1577) was the first analysis of all seven books, as he himself observes proudly. Previously only partial studies on separate books had been written by Galen, Leonhard Fuchs

\footnotetext{
${ }^{26}$ Gaspar Casal gave the name of 'the rose illness' ('el mal de la rosa') to pellagra. With respect to Gaspar Casal see Granjel (1979) 31 f. and Peset Reig (2002) 223-228.

${ }^{27}$ On Spanish Renaissance medicine see Granjel (1980).

28 Liber Prognosticorum Hippocratis (Lyon 1551) and Commentaria in librum Aphorismorum (Lyon 1563?).

${ }^{29}$ On the style of Cristóbal de Vega see Martín Ferreira (1995) 193-198.

${ }^{30}$ Commentaria in Prognosticum Hippocratis (Alcalá de Henares 1567).
} 
(1501-1566) or the Spanish Pedro Jaime Esteve (d. 1566). ${ }^{31}$ As an example of the reputation of Valles, we can mention that a collected edition of several works about Hippocrates was published in Paris in 1663 and that there were more than 70 reprints of his books in Europe.

To sum up, Piquer's thought and conception of medicine is a symbiosis of the best Spanish traditions and of the contemporary trends. As a product of the latter we can relate his interest in improving the teaching of medicine, which is reflected in his Institutiones medicae ad usum Scholae Valentinae (Madrid, 1762) and his Praxis Medica ad usum Scholae Valentinae (Madrid, in two volumes, 1764-1766). Both writings, belonging to the last period of Piquer's creation, were official texts for the students of medicine at the University of Valencia. In both texts as well as in his rewriting of earlier treatises during this period, especially noteworthy is Piquer's disagreement with the systematic theories of Boerhaave about the mechanics of the body, where Piquer even dared to criticize the inconsistency of the reasonings of the Dutch doctor, although hereeognized their utility for the students:

Hunc Auctorem (scil. Boerhaave), qui alia quamplurima scripsit commendatione dignissima, legant Tyrones, \& venerentur. Attamen sciant oportet, duo esse in Boerahavii scriptis consideranda, observationes, scilicet, \& ratiocinia. Si observationes spectes, nihil exactius: si ratiocinia, more saeculi multum habent pulchritudinis. "utilitatis parum; negari enim nequit, quin plurima Boerahavii themata, aut incerta sint, aut non sat firmis fundamentis statuta. ${ }^{32}$

Furthermore, it must be pointed out that the doctrine of Boerhaave was always received with criticism in Spain because anti-systematic

${ }^{31}$ Francisco Valles writes the following to King Philip II in the beginning of the dedication of his commentary:

..., scribere decrevi, ea praecipue causa, quod nullius neque veterum neque recentium, extent, aut (quod equidem sciam) extiterint unquam integra commentaria. Galeni enim extant adhuc in primum, tertium \& sexti partem: scripsit vero, ut eiusdem constat testimonio, etiam in secundum: recentiores in minora frustra secant. Leonhartus Fuchsius scripsit in sextum. Petrus Iacobus Esteve in secundum. Quartum, quintum \& septimum nullus attigit, ac proinde a plerisque (iniuria ut censeo) habentur despecti $i$, quasi alieni \& spurii. [apud Martín Ferreira (1995) 60 note 44].

32 Medicina vetus, et nova postremis curis retractata, \& aucta ad usum Scholae Valentinae, Madrid 1768, fourth edition, XLI. In the third edition (Madrid 1758), Piquer included a Prologue, reprinted in the fourth, which contained an introduction to the history of medicine according to his eclectic conception of this science. Moreover, in the fourth edition and following the doctrines of his Institutiones medicae..., he eliminated all the references to mechanistic theories. 
movements were deeply rooted in the country. Hence, it would be better to speak about the influence of Boerhaave as explained and illustrated by van Swieten, his main pupil, whom Piquer considered as the prototype of a good doctor:

GERARDUS VANSWIETENIUS, BOERAHAVII per plures annos Auditor, commentarios edidit in ejus Aphorismos de cognoscendis, \& curandis morbis, vera Medicinae sapientia refertos. In iis invenient Tyrones quidquid solidum, \& utile ab antiquitate circa morborum indolem, \& curationem, dictum, interimque novas nostrorum saeculorum observationes longo usu probatas in usum practicum, \& veterum illustrationem adducit. Ea omnia complectitur stilo puro, gravi, perspicuo, adeo, ut ejus lectio utilis Tyronibus esse possit. Piquer, Medicina vetus, et nova postremis curis retractata, \& aucta ad usum Scholae Valentinae, Madrid 1768, fourth edition, XLH.

On the other hand, Piquer had a crucial bearing on the development of clinical medicine in Spain, particularly in Valencia at the University where he taught. The increasing importance of clinical medicine is evident in the reform of the Programme of medicine at the University of Valencia in 1786, 14 years after Piquer's death. ${ }^{33}$ His influence can be seen in the introduction of teachings of the Alte Wiener Schule, like, for example, the works of Maximilian Stoll (1742-1787) based on the daily observation at the bedside of the patients related with the meteorological phenomena. According to this conception of medicine, the hospital became the place to teach and subsequently it opened its doors to students. Thus, many hospitals improved their installations and equipment, and the doctor began to play the main role in the direction of the hospital to the detriment of Church power, which still controlled and managed many of these institutions. Every teacher was in charge of a hospital ward with 20 patients and chose one or two students to look after a patient and to write his case-history. The teacher also appointed two students to keep statistics on the hospital's discharged and dead and to report on dissections and weather conditions. All this material was collected, reviewed and filed. ${ }^{34}$

\footnotetext{
${ }^{33}$ About this reform see Peset Reig (1973).

${ }^{34}$ On the significance of the clinical medicine in Valencia see López Piñero (1973) 202209, and Peset Reig (1973) 245-247 and (2002) 231-234. The origins of these studies at the University of Valencia can be found in Luis Collado (ca. 1520-1589), who wrote interesting works on pathology, therapeutic and clinical medicine, was an experienced anatomist and held the chair of practical medicine created at his request with the main
} 
On balance, we have to conclude that Piquer epitomized a period of changes and progress, which collapsed abruptly because of many factors. His Hippocratic conception of medicine tried to combine the ancient tradition with the contemporary European medical trends, which were within the reach of Spanish scientists thanks to the policy of the time, open to new ideas from abroad. From the medical point of view, Piquer exerted a great influence on the generations of doctors that followed, as was to be expected because many books were the official texts at several Universities, especially in Valencia. Nevertheless, it must be stated that Piquer did not found a school, probably due to his anti-systematic and eclectic vision of medicine, which was opposed to a rigid and closed corpus of teachings. However, he had some success abroad since several works were reprinted in Europe, like his Praxis Medica (Amsterdam, 1775, and Venice, 1776), or were translated from Spanish into French, like his Traité des fièvres (Tratado de las calenturas) and his commentary to Prognostic, or from Latin into Portuguese, like his Praxis Medica. ${ }^{35}$

Finally, let us conclude by saying that, in our opinion, it is very important to observe that Piquer's work would have been inconceivable and almost impossible to do in the Spain of the latter days of the House of Habsburg and in that of later Bourbon monarchs, who once again isolated Spain from contemporary European scientific currents.

\section{Bibliography}

Abellán, J.L. (1988²), Historia crítica del pensamiento españot: Del Barroco a la Ilustración (siglos XVII y XVIII), Madrid 1981 [Vol. III].

Ángel y Espinós, J. (1998), ‘Andrés Piquer et la tradition hippocratique dans l'Espagne du XVIIIe siècle', Vesalius 4, 1, 31-34.

- (2002), "Andrés Piquer y la “cuestión hipocrática", in: J.Ma Maestre Maestre, J. Pascual Barea \& L. Charlo Brea (eds), Humanismo y pervivencia del mundo clásico. Homenaje al profesor Antonio Fontán (Alcañiz/Madrid), 2551-2556 [Vol. V].

- 'El "hipocratismo" de Andrés Piquer' (in press).

Cunningham, A. (2002), 'The transformation of Hippocrates in seventeenth-century Britain', in: D. Cantor (ed.), Reinventing Hippocrates (Cornwall Aldershot etc.), 91115.

Granjel, L.S. (1972), ‘Traducciones castellanas de Hipócrates', in: A. Tovar Llorente \& F. Rodríguez Adrados (eds), Homenaje a Antonio Tovar (Madrid), 169-176.

goal of teaching students how to heal patients. See Granjel (1980) 28, 47 f. and 156158, and López Piñero (1987) $12 \mathrm{f}$.

${ }^{35}$ For information about the dates of the Spanish editions as well as for the foreign editions and translations see Mindán Manero (1991) 58-97. 
- (1979), La medicina española del siglo XVIII, Salamanca.

- (1980), La medicina española renacentista, Salamanca.

Guy, A. (1983), Histoire de la philosophie espagnole, Toulouse.

Holub, N. (1976), 'The Enlightenment in Valencia: Effects and counter-effects', in: Universidad de Valencia (ed.), Primer Congreso de Historia del País Valenciano (Valencia), 829-834 [Vol. III].

Laín Entralgo, P. (1950), La historia clínica: Historia y teoría del relato patográfico, Madrid [repr. 1998].

López Férez, J.A. (1983), ‘Aforismos: Introducción, traducción y notas', in: Tratados hipocráticos, ed. C. García Gual (Madrid), 211-297 [repr 1990], [Vol. I].

López Piñero, J.Ma (1973), 'La mentalidad antisistemática en la medicina española del siglo XVIII: La influencia de la Alte Wiener Schule', Cuadernos de Historia de la Medicina Española 12, 193-212.

- (1987), Introducción. Andrés Piquer y el hipocratismo en la España de la ilustración, in: Andrés Piquer, Las Epidemias de Hippócrates con observaciones prácticas de los antiguos y modernos (sic) (Madrid), 9-37 [facsimile version].

Martensen, R.L.(2001), 'Hippocrates and the politics of medical knowledge in early Modern England', in: D. Cantor (ed.), Reinventing Hippocrates (Cornwall Aldershot etc.), 116-135.

Martín Ferreira, A.I. (1995), El humanismo médico en la Universidad de Alcalá (Siglo $X V I)$, Alcalá de Henares.

Martínez Pérez, J. \& Santamaría Hernández, Mª.T. (2002), Introducción, in: Alonso Manuel Sedeño de Mesa, Traducción de los Aforismos de Hipócrates y del Capítulo Áureo de Avicena, por Alonso Manuel Sedeño de Mesa, natural de Albacete, (... ) En Madrid, en la Imprenta de Manuel Ruiz de Murga, Año de 1699 (Cuenca), 11-84 [facsimile edition].

Mindán Manero, M. (1991), Andrés Piquer: Filosofía y medicina en la España del siglo XVIII, Zaragoza.

Perdiguero, E. (1992), 'The popularization of medicine during the Spanish Enlightenment', in: R. Porter (ed.), The Popularization of Medicine. 1650-1850 (London/New York), 160-193.

Peset i Llorca, V. (1975), Gregori Mayans i la cultura de la illustració, Barcelona/Valencia.

Peset Reig, J.L. (1973), 'Reforma de los estudios médicos en la Universidad de Valencia: El plan de estudios del rector Blasco de 1786', Cuadernos de Historia de la Medicina Española 12, 213-264.

- (2002), 'La enfermedad y los médicos', in: J.L. Peset Reig (ed.), Historia de la ciencia y de la técnica en la corona de Castilla. Siglo XVIII (Salamanca), 215-237 [vol. IV].

Piquer y Arrufat, A. (1757), Las obras de Hippócrates más selectas con el texto griego $y$ latino puesto en castellano e ilustrado con las observaciones prácticas de los antiguos y modernos para la juventud española que se dedica a la medicina, por el Dr. Andrés Piquer, ed. J. Ibarra, Madrid http://alfama.sim.ucm.es/dioscorides/consulta libro.asp?ref $=$ X532220748\&idioma $=$ $\underline{0}$ (October 2008)].

- (1761), Las obras de Hippócrates más selectas, ilustradas por el Dr. Andrés Piquer, ed. Joaquín Ibarra, Madrid [http://alfama.sim.ucm.es/dioscorides/consulta libro.asp?ref=X532222244\&idioma $=0$ (October 2008)]. 
- (1770), Las obras de Hippócrates más selectas, ilustradas por el Dr. Andrés Piquer, ed. Joaquín Ibarra, Madrid [tomo III online: http://alfama.sim.ucm.es/-

dioscorides/consulta libro.asp? $r e f=X 532222325 \&$ idioma $=0$ (October 2008)].

Santander Rodríguez, T. (1971), Hipócrates en España. Siglo XVI, Madrid.

Sanvisens Marfull, A. (1953), Un medico-filósofo español del siglo XVIII: El doctor Andrés Piquer, Barcelona.

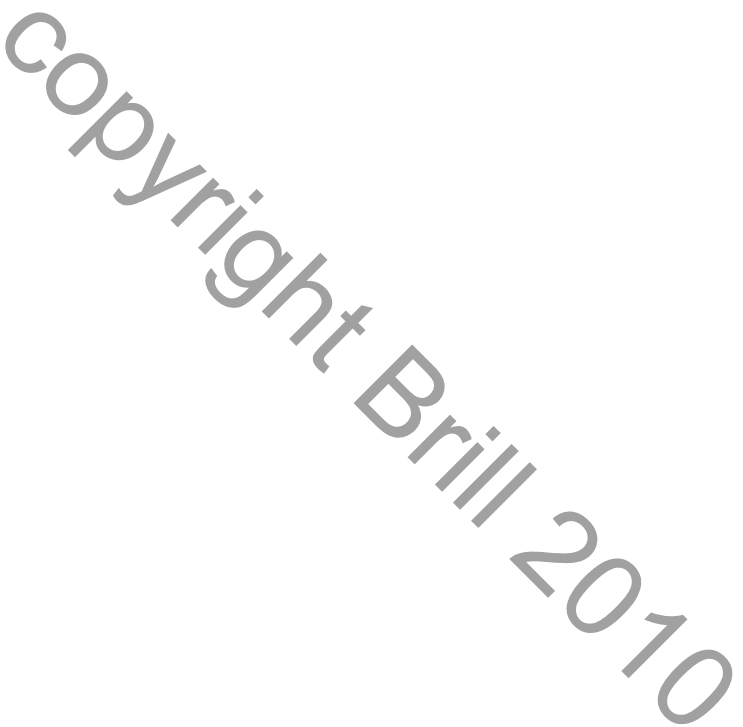

